\title{
Konsep Pendidikan Anak Pada Masyarakat Betawi
}

\author{
Mahmudah Fitriyah Z.A \\ UIN Syarif Hidayatullah Jakarta, Indonesia \\ E-mail: mahmudah.fitriyah@uinjkt.ac.id
}

\begin{abstract}
The topics of education always interest to be discused. Indonesia as a developing country should be vigorous in paying attention to the problems of the children as the nation's next generation, especially in the field of education. Economic demands that are not balanced with the ease of getting education are interesting to be discussed as well. Educational facilities and infrastructure are growing rapidly. Nonetheless, there are some of our society who think that education is not important. Moreover, if education associated with women, there are plenty of our society who think that girls do not need a higher education. These phenomena are often heard in our society. The reluctance for going to school or college is a problem that has not been answered yet up to now. The story of campus life around them does not have an impact on their mindset about education. Hence, this research aimed to investigate the problem. This research is conducted by using qualitative method with observation and interview. This research is expected to gather data about the concept of education for girls on Betawi society. The innitial background of this research is that there is a presumption that the Betawi society who have a desire to work quickly but 'lazy to school' become interesting to be studied. In addition, they live adjacent to the campus then why their mindset remains unchanged?
\end{abstract}

Keywords: the concept of education; girl; Betawi society

Abstrak. Pembicaraan tentang pendidikan selalu menjadi hal yang menarik. Indonesia sebagai negara berkembang seharusnya gencar dalam memperhatikan persoalan anak bangsa sebagai generasi penerus bangsa khususnya dalam bidang pendidikan. Tuntutan ekonomi yang tidak seimbang dengan mudahnya mendapatkan pendidikan menjadi satu hal yang menarik. Fasilitas mencakup sarana dan prasarana pendidikan berkembang dengan pesat. Tapi, disayangkan masih ada sebagian masyarakat kita yang menganggap pendidikan bukanlah hal penting. Apalagi jika dikaitkan dengan perempuan, masih banyak masyarakat kita yang menganggap anak perempuan tidak perlu sekolah tinggi-tinggi. Apalagi sampai jenjang perguruan tinggi. Fenomena ini begitu sering terdengar di masyarakat kita. Keengganan untuk bersekolah lanjut atau ke perguruan tinggi menjadi suatu tanda tanya yang tidak pernah terjawab sampai saat ini. Hingar-bingarnya kehidupan kampus di sekitar mereka ternyata tidak berdampak pada pola pikir mereka tentang pendidikan. Penelitian ini menggunakan pendekatan kualitatif, yaitu melakukan pengamatan dan percakapan langsung. Penelitian ini diharapkan dapat mengumpulkan data tentang konsep-konsep pendidikan bagi anak perempuan pada masyarakat Betawi. Dugaan awal penelitian ini adalah, masyarakat Betawi yang kecenderungan ingin cepat bekerja, tapi 'malas sekolah' menjadi menarik untuk diteliti, apalagi tempat tinggal mereka yang berdekatan dengan dunia kampus, mengapa pola pikir mereka tetap tidak berubah?.

Kata Kunci: konsep pendidikan; anak perempuan; masyarakat betawi

Permalink/DOI: 10.15408/harkat.v14i1.10401

Jurnal Harkat : Media Komunikasi Gender, 14 (1), 2018, p-ISSN: 1412-2324, e-ISSN: 2655-7428

This is an open access article under CC-BY-SA license (https://creativecommons.org/licenses/by-sa/4.0/) 


\section{Pendahuluan}

Pendidikan memiliki peran penting dalam kehidupan manusia. Salah satu di antaranya pendidikan adalah sebagai media yang berfungsi menjadikan manusia lebih baik dari sebelumnya. Peran penting lainnya yang sering terdengar pendidikan untuk memanusiakan manusia. Akan tetapi, pada kenyataannya banyak di antara kita yang kurang memahami pendidikan secara mendasar. Sebagian orang hanya memahami secara garis besar saja yaitu, bahwa pendidikan hanya sebagai sarana belajar, terutama sarana belajar dalam bidang akademis. Sebagian yang lain beranggapan bahwa pendidikan merupakan salah satu motor penggerak perubahan sosial. Khusus bagi perempuan, pendidikan adalah kunci menuju kehidupan yang lebih baik. Mengapa saya katakan demikian? Perjalanan sejarah yang panjang dari seorang Cut Nyak Dien, Rohana Kudus, Kartini, Dewi Sartika dan tentunya pejuang-pejuang wanita lainnya telah memberikan warna pendidikan menjadi cakupan manfaat yang lebih luas, bukan hanya pada diri perempuan itu sendiri melainkan meliputi seluruh perempuan khususnya yang menjadi warga negara Indonesia, nama-nama tersebut begitu sangat mempengaruhi sepak terjang perjalanan wanita di Indonesia hingga sekarang ini.

Tuntutan zaman yang laju perkembangannya semakin kompleks, maka persaingan hidup pun semakit ketat. Orang yang mampu menyesuaikan diri terhadap lingkungannya akan bertahan hidup di tempat yang ia tinggali. Seseorang dapat bertahan dalamlingkungannya itu sebab mempunyai kemampuan dan potensi yang ada dalam dirinya. Kemampuan dalam potensi itu dapat direalisasikan dalam bentuk ilmu pengetahuan dan keterampilan, kalau itu betul-betul dalam sistem yang baik, yaitu pendidikan.

Pendidikan tidak hanya sekedar terbatas pada bangku sekolah dan waktu yang dilalui di bangku akademik. Namun, pendidikan itu tidak terbatas hanya pada hal tersebut dan juga tak berbatas umur. Oleh sebab itu, mestinya pendidikan diartikan tidak berbatas waktu. Proses belajar yang dimaksud adalah belajar yang berlangsung setiap saat dan dimana pun dia berada atau dalam istilah lain adalah Life long education. Prinsip pendidikan seperti ini akan memberikan kesempatan kepada setiap orang sepanjang hidupnya untuk dapat terus belajar secara terorganisir sehingga akan menciptakan perubahan baru terhadap setiap individu dalam perkembangan hidupnya, yang pada akhirnya mampu hidup dengan baik.

Tingkat pendidikan perempuan berpengaruh signifikan terhadap kualitas kesehatan anak. Sebuah kajian Bank Dunia berjudul Gender Equality and the Millennium Development Goals (2003) menunjukan bahwa rendahnya tingkat pendidikan dan tingginya angka buta huruf ibu berdampak langsung terhadap maraknya gizi buruk akibat rendahnya kualitas pengasuhan bayi dan anak balita. Kajian tersebut menunjukan temuan di 25 negara berkembang, dimana perempuan yang tinggal di bangku sekolah satu hingga tiga tahun lebih lama mampu menurunkan 15\% angka kematian anak, sedangkan jangka waktu pendidikan yang sama bagi ayah menurunkan hanya $6 \%$ angka kematian anak. Perempuan yang berpendidikan, saat dia menjadi ibu, dia akan paham peran gizi, sanitasi dan kesehatan yang baik bagi kesehatan dirinya dan anaknya.

"Kaum perempuan sudah mengalami kemajuan untukmendapat akses dalam pembangunan. Namun budaya patriarki masih menyebabkan pencapaian perempuan dibanding laki-laki lebih rendah. Meski usia harapan hidup perempuan meningkat, tetapi angka melek huruf dan rata-rata lama sekolah pada laki-laki masih lebih tinggi dibanding perempuan," kata Linda Amalia Sari Gumelar (Seminar Teleconference Koalisi Kependudukan, 2012). 
Terlepas dari fakta tersebut, di berbagai belahan dunia masih hidup tradisi yang menomorduakan perempuan dalam berbagai bidang kehidupan termasuk pendidikan. Fenomena bahwa perempuan Indonesia masih banyak yang berpendidikan rendah menjadi tamparan bagi dunia pendidikan saat ini. Anggapan bahwa perempuan hanya berfungsi sebagai 3R yaitu dapur, sumur, dan kasur harus segera dihapuskan sehingga tidak ada lagi ketimpangan sosial. Untuk mewujudkan pendidikan berkualitas bagi kaum perempuan maka harus ada jaminan pendidikan, seluruh perempuan tidak boleh hanya menamatkan pendidikan sampai pada jenjang pendidikan dasar saja namun minimal harus pada jenjang SLTA, dan tentunya akan lebih baik lagi bila sampai jenjang perguruan tinggi. Pola pikir seperti itu seharusnya menempel pada semua perempuan Indonesia.

Perubahan pola pikir memang tidak dapat terjadi dengan begitu cepat, akan tetapi bisa dihitung jari bagi keluarga Betawi yang melanjutkan pendidikan ke jenjang SLTA dan Perguruan Tinggi. Fenomena ini menjadi menarik, apalagi ketika kita menyaksikan film $S i$ Doel Anak Sekolahan yang ditayangkan di telivisi dan begitu banyak penonton dan penggemarnya. Si Doel yang menjadi "Tukang Insinyur" begitu menempel dalam ingatan kita. Pengaruh film itupun ternyata memberi gambaran berbeda dengan kenyataan. Karena pola pikir masyarakat sekali lagi tidak terpengaruhi. Lalu ada apa sebenarnya dengan konsep pendidikan pada perempuan Betawi?

Seperti yang dituturkan oleh Wahyudi Akmaliah Muhammad salah satu mahasiswa pascasarjana yang notabene asli Betawi, "Menjadi Betawi adalah problem. Inilah yang saya rasakan dengan identitas kebetawian saya. Setiap berkenalan dengan seseorang, dan kemudian berlanjut pada pertanyaan mengenai asal kelahiran, seringkali pertanyaan cenderung pada “orang Jakarta asli atau bukan?". Jika bukan, maka pertanyaan tidak akan berlanjut. Namun, jika Jakarta "asli", maka pertanyaan tersebut akan disusul dengan ungkapan bernada takjub dan rasa tidak percaya. "Masa sih", "ah yang benar", "enggak mungkin” orang Betawi bisa kuliah hingga ke jenjang lebih tinggi. Ada rasa kebanggaan ketika orang tidak percaya bahwa saya orang betawi yang sedang menempuh pascasarjana yang juga sering diamini juga oleh orang Betawi pada umumnya."

Pertanyaan seperti di atas tentunya sudah sering kita temukan, terkait dengan identitas orang Betawi, hal ini mengusik saya untuk menelusuri lebih jauh di balik asumsi itu. Apakah itu hanya sekedar pertanyaan? Ataukah ada jejak tanda di balik semua itu? Sebenarnya pertanyaan-pertanyaan tersebut merupakan bentuk inferioritas dalam memandang orang Betawi. Selama ini orang Betawi dalam pandangan masyarakat Indonesia adalah orang yang tidak berpendidikan, mau menang sendiri, tukang kawin, malas, kasar, tidak punya sopan santun, dan streotif negatif lainnya. Ketika melihat orang Betawi yang berpendidikan, pekerja keras, dan berprestasi, mereka menjadi sangsi, karena merasa apa yang dilihat tidak sesuai dengan yang ada dalam pikiran mereka selama ini.

Peneliti ingin memakai pendekatan etnografi karena menurut Ary, dkk. etnografi adalah studi mendalam tentang perilaku alami dalam sebuah budaya atau seluruh kelompok social (Donald Ary, dkk., 2010:459). Lebih jauh Creswell menyatakan, Metode etnografi adalah prosedur penelitian kualitatif untuk menggambarkan, menganalisa, dan menafsirkan unsur-unsur dari sebuah kelompok budaya seperti pola perilaku, kepercayaan, dan bahasa yang berkembang dari waktu ke waktu (Jhon W. Cresswell, 2012:462). Fokus penelitian ini adalah budaya. Budaya itu sendiri jika kita 
cermati tentunya mencakup banyak aspek yang diantaranya segala sesuatu yang berkaitan dengan perilaku manusia dan keyakinan, termasuk bahasa, ritual, tahapan kehidupan, interaksi, ekonomi, gaya komunikasi, dan lain sebagainya.

Penelitian ini mencoba melihat konsep pendidikan bagi anak perempuan Betawi di wilayah Ciputat, Tangerang Selatan. Peneliti yang tinggal di wilayah ini sudah cukup lama bergaul dan mengamati sikap dan aktivitas masyarakat Betawi di sini, terutama dalam hal pendidikan untuk anak perempuan. Sudah beberapa tahun bergaul dengan masyarakat di daerah ini, saya menjumpai sangat sedikit keluarga Betawi yang menyekolahkan anak perempuannya sampai perguruan tinggi. Hal ini menjadi menarik karena di daerah ini terdapat beberapa kampus besar diantaranya: UIN Syarif Hidayatullah, Institut Ilmu al Qur'an (IIQ), Universitas Pamulang (UNPAM), terdapat puluhan SLTP dan SLTA. Hal ini menunjukkan bahwa fasilitas terkait pendidikan sudah cukup memadai. Tetapi ternyata lingkungan yang sudah begitu hiruk-pikuknya dengan dunia pendidikan, nyaris tak mengubah pola pikir mereka.

Pendidikan bagi perempuan juga berdampak langsung terhadap penurunan angka kematian ibu saat melahirkan. (UN Women, 2015). Logikanya semakin lama perempuan duduk di bangku sekolah berdampak pada semakin tinggi usia pernikahan, yang berarti pula mengurangi resiko kematian akibat hamil dan melahirkan terlalu muda.

Pendidikan bagi perempuan berdampak pula terhadap meningkatnya pendidikan anak. Setiap satu tahun penambahan waktu ibu di bangku sekolah berdampak terhadap penambahan 0,32 tahun pendidikan anak (UN Women, 2015). Logikanya perempuan yang berpendidikan paham pentingnya pendidikan dan saat menjadi ibu dia akan menjadi pendukung utama pendidikan anak-anaknya.
Orang tua merupakan pendidik pertama bagi anak-anak mereka, karena dari merekalah anak mula-mula menerima pendidikan. dengan demikian bentuk pertama dari pendidikan terdapat dalam kehidupan keluarga. Begitu si anak lahir, dibisikkan di telinganya kalimah adzan dan iqamah, dengan harapan kata-kata thaiyibah itulah hendaknya yang pertama kali didengar oleh anak, kemudian dia akan berulang kali mendengarnya, setiap waktu shalat tiba, baik di dengar di rumahnya atau pun di luar rumah. Kata-kata thaiyibah dan kata-kata lainnya yang berisikan jiwa agama akan sering didengar oleh anak melalui ibunya, ketika si anak disusukan, dimandikan, ditidurkan, dan diganti baju oleh ibunya. Pengalaman yang seperti ini akan menyuburkan tumbuhnya rasa agama di dalam jiwa anak, dan akan tetap hidup di dalam jiwanya.

Menurut Zakiah Daradjat (1996), Pada umumnya pendidikan dalam rumah tangga ini bukan berpangkal tolak dari kesadaran dan pengertian yang lahir dari pengetahuan mendidik, melainkan karena secara kodrati suasana dan strukturnya memberikan kemungkinan alami membangun situasi pendidikan. Situasi pendidikan itu terwujud berkat adanya pergaulan dan hubungan pengaruh-mempengaruhi secara timbale balik antara orang tua dan anak.

Dari uraian di atas jelaslah bahwa penciptaan situasi yang baik itu adalah usaha mencipkan terwujudnya saling mengerti, saling menerima, saling menghargai, saling mempercayai, dan saling menyayangi sesame anggota keluarga, baik antara ibu dan bapak, ibu dan anak, bapak dan anak, dan begitu pula sebaliknya.

Pengaruh lingkungan keluarga terhadap perkembangan anak sejak dini adalah sangat mendalan dan menentukan perkembangan pribadi anak selanjutnya. Hal ini disebabkan: 1) Pengaruh itu merupakan pengalaman yang 
pertama-tama; 2) Pengaruh yang diterima anak itu masih terbatas jumlah dan luasnya; 3) Intensitas pengaruh itu tinggi karena berlangsung terus-menerus siang dan malam; 4) Umumnya pengaruh itu diterima dalam suasana aman serta bersifat intim dan bernada emosional. (Ngalim Purwanto, 1987)

Ngalim juga menambahkan, bahwa peranan seorang ibu dalam pendidikan anakanaknya adalah sebagai sumber dan pemberi rasa kasih sayang, pengasuh, dan pemelihara, tempat mencurahkan isi hati, pengaruh kehidupan dalam rumah tangga, pembimbing hubungan pribadi, dan pendidik dalam segi-segi emosional.

Terlepas dari fakta tersebut, di berbagai belahan dunia masih hidup tradisi yang menomorduakan perempuan dalam berbagai bidang kehidupan termasuk pendidikan. Tugas kita semua untuk memajukan bangsa ini melalui pendidikan yang berkualitas dan menghapuskan diskriminasi dalam pendidikan bagi perempuan dan kelompok marginal lain.

Perkembangan teknologi yang begitu pesat kita rasakan dalam segala bidang, tentunya menuntut manusia yang memiliki keilmuan dan keterampilan yang memadai. Pengetahuan tidak memandang jenis kelamin, siapa dan dimana saja boleh menikmati atau mendapatkan ilmu pengetahuan. Masyarakat Betawi yang sering terdengar adalah sebutan "raja tanah", artinya mereka adalah penduduk asli yang memiliki lahan tempat tinggal yang luas. Pembangunan yang begitu pesat dan perpindahan penduduk dari desa ke kota, membuat masyarakat Betawi tersisih. Banyak di antara mereka yang sedikit demi sedikit menjual lahan atau tanah (kebun) untuk kelangsungan hidup mereka. Bekal pengetahuan yang minim terhadap generasi penerus mereka menyebabkan lapangan kerja yang baik tak pernah dapat dicapai. Tamat SD atau SMP, menyebabkan mereka hanya dapat bekerja di kelas bawah. Hal ini terus berlangsung selama bertahun-tahun. Lalu bagaimana dengan perempuan-perempuan Betawi?

Hal ini menjadi menarik untuk ditelaah lebih jauh, apalagi tempat yang akan menjadi objek penelitian ini adalah mereka menetap/tinggal tidak jauh dari kampus UIN Jakarta, artinya begitu dekatnya mereka dengan dunia pendidikan, apakah keberadaan kampus tidak mengubah pola pikir mereka tentang pendidikan?.

\section{Metode}

Penelitian ini menggunakan metode deskriptif. Metode penelitian deskriptif yang digunakan dalam penelitian ini adalah pendekatan kualitatif. Pendekatan kualitatif yang dimaksud mengacu kepada prosedur penelitian yang menghasilkan data-data deskriptif.

Menurut Suparlan, "Pendekatan kualitatif yaitu pendekatan yang digunakan untuk memahami prinsip-prinsip umum yang mendasari sesuatu gejala yang menjadi pusat perhatian penulis dan hubngan antara gejalagejala yang terlibat di dalamnya (Parsudi Suparlan, 1996: 41).”

Sugiyono menyatakan, "Penelitian kualitatif adalah metode yang sering disebut metode penelitian naturalistik karena penelitiannya dilakukan pada kondisi yang alamiah (natural setting). Selain itu penelitian kualitatif juga disebut sebagai metode etnografi, karena pada awalnya metode ini lebih banyak digunakan untuk penelitian bidang antropologi budaya(Sugiyono, 2012:14).”

Sedangkan menurut Whitney dalam buku Moh. Nazir menyatakan penelitian kualitatif adalah pencarian fakta dengan interpretasi yang tepat. Penelitian deskriptif mempelajari masalahmasalah dalam masyarakat, serta ada cara yang berlaku dalam masyarakat serta situasi-situasi tertentu, termasuk tentang hubungan, kegiatan- 
kegiatan, sikap-sikap, pandangan-pandangan serta proses-proses yang sedang berlangsung dan pengaruh-pengaruh dari suatu fenomena (Moh. Nazir, 2011: 55).

Dengan menggunakan penelitian deskriptif ini peneliti bertujuan untuk dapat menggambarkan berbagai fenomena realitas sebenarnya yang menjadi obyek penelitian agar lebih mendalam dan memperoleh data yang diinginkan dengan melihat dan mempelajari gejala-gejala/masalah-masalah pendidikan perempuan di masyarakat Betawi, di daerah Ciputat, Tangerang Selatan.

\section{Hasil dan Pembahasan}

Disadari ataupun tidak, sejak pertama kali kita dilahirkan ke dunia sebenarnya kita telah menerima pendidikan. Pendidikan tersebut adalah pemberian orang tua kita, kita dididik bagaimana mendengarkan, berbicara, berjalan, makan, mandi, memakai baju, dan semua hal yang mendasar dalam kehidupan ini. Seiring dengan bertambahnya usia maka pendidikan yang kita terima pun semakin banyak. Umur 4 tahun kita mulai mengenal dunia pendidikan formal dengan taman kanak-kanak, sekolah dasar, SMP, SMA, hingga akhirnya pendidikan di perguruan tinggi.

Sistem pendidikan mempunyai tugas tersirat atau tersurat untuk mempersiapkan setiap orang agar mampu memainkan peran sosialnya. Di dalam masyarakat-masyarakat yang rumit sekarang ini, setiap hari pada kenyataannya di dalam pekerjaan, kegiatankegiatan budaya, dalam perkumpulan, semua anggota masyarakat haruslah masing-masing memikul tanggung jawab terhadap orang lain. Oleh karena itu, sekolah-sekolah haruslah mempersiapkan penduduk untuk mampu memainkan peran ini dengan jalan mengajr mrreka tentang hak-hak dan kewajibankewajibannya, dan juga dengan jalan mengembangkan keterampilan soaial mereka dengan mendorong kemampuan dan kemauan bekerja dalam kelompok.

Secara umum pengertian pendidikan adalah merupakan usaha yang dilakukan secara sadar oleh semua elemen yang ada di sekitar kehidupan kita, baik itu orang tua, keluarga, sahabat, ataupun masyarakat secara umum, serta lembaga-lembaga pendidikan baik yang resmi dan formal yang dibentuk oleh pemerintah dan pihak yang bertanggung jawab di Indonesia, ataupun lembaga-lembaga nonformal. Pendidikan sendiri bermacam-macam, ada pendidikan umum, pendidikan khusus, pendidikan kejuruan, pendidikan akademik, pendidikan profesi, pendidikan karakter, pendidikan vokasi, hingga pendidikan agama.

Kembali ke pendidikan dan kebudayaan, tampaknya bahaya utama dari teknologiteknologi baru ini adalah terciptanya pemisahan dan disparitas. Disparitas baru yang mungkin timbul antara berbagai masyarakat, yakni antara masyarakat-masyarakat yang sudah mampu menyesuaikan diri dengan teknologi ini dan masyarakat-masyarakat yang belum mampu berbuat demikian, karena kekurangan dana atau kemauan politik (W.P. Napitupulu, 1999:47).

Kemajuan teknologi yang amat pesat mungkin juga berdampak pada penawaran prospek baru untuk pembangunan dengan membuka sejumlah besar daerah terpencil dan memberikan kemampuan penduduk untuk dapat berkomunikasi dengan masyarakat di seluruh dunia. Ini menjadi peran pendidikan untuk melengkapi anak-anak dan orang-orang dewasa dengan latar belakang budaya, sedapat mungkin memahami perubahan-perubahan yang terjadi. Sehingga pada akhirnya mereka dapat memilah-milah informasi yang banyak itu dan mampu menafsirkannya dengan tepat manfaatnya.

Dalam Kamus Besar Bahasa Indonesia, kata 'pendidikan' mempunyai arti proses atau 
cara atau perbuatan mendidik. Secara bahasa, definisi pendidikan adalah proses pengubahan sikap dan tata laku seseorang atau kelompok orang dalam usaha mendewasakan manusia melalui upaya pengajaran dan pelatihan.

\section{Pengertian} pendidikan di dalam UU Sisdiknas No.20 tahun 2003 adalah usaha sadar dan terencana untuk mewujudkan suasana belajar dan proses pembelajaran agar peserta didik secara aktif mengembangkan potensi dirinya untuk memiliki kekuatan spiritual keagamaan, pengendalian diri, kepribadian, kecerdasan, akhlak mulia, serta keterampilan yang diperlukan dirinya, masyarakat, bangsa, dan negara.

Menurut Mahmud Yunus, yang dimaksud pendidikan adalah "Suatu usaha yang dengan sengaja dipilih untuk mempengaruhi dan membantu anak yang bertujuan untuk meningkatkan ilmu pengetahuan, jasmani dan akhlak sehingga secara perlahan bisa mengantarkan anak kepada tujuan dan citacitanya yang paling tinggi. Agar memperoleh kehidupan yang bahagia dan apa yang dilakukanya dapat bermanfaat bagi dirinya sendiri, masyarakat, bangsa, negara dan agamanya."

Uraian di atas begitu luasnya, jika seseorang mendapatkan pendidikan yang dicitacitakan maka dia akan memperoleh kehidupan yang bahagia. Ilmu yang didapatpun hendaknya bermanfaat khususnya untuk dirinya sendiri atau untuk masyarakat pada umumnya. Hal ini menunjukkan bahwa betapa pentingnya sebuah pendidikan.

Menurut M. J. Langeveld seorang ahli pendidikan bangsa Belanda, "Pendidikan merupakan upaya dalam membimbing manusia yang belum dewasa ke arah kedewasaan. Pendidikan adalah suatu usaha dalam menolong anak untuk melakukan tugas-tugas hidupnya, agar mandiri dan bertanggung jawab secara susila. Pendidikan juga diartikan sebagai usaha untuk mencapai penentuan diri dan tanggung jawab."

Lengeveld lebih menekankan pada tanggung jawab dan kemandirian dalam sebuah pendidikan. Dia jelas menitikberatkan pendidikan pada upaya bimbingan manusia menuju ke arah kedewasaan. Lengeveld juga menyatakan bahwa pendidikan adaah pemberian bimbingan atau bantuan rohani bagi yang masih memerlukan. Dalam hal ini lengeveld menegaskan bahwa tidak semua pengaruh dari seseorang yangtelah dewasa kepada orang yang belum dewasa itu disebut mendidik. Sebab mungkin saja pengaruhnya itu tidak mengandung unsure mendidik sama sekali. Lengeveld menggarisbawahi bahwa sifat dari mendidik ialah bahwa semua usaha, pengaruh, perlindungan, serta bantuan yang diberikan harus tertuju kepada kedewasaan anak didiknya atau dengan perkataan lain membantu anak didik agar cukup cakap dalam menjalankan tugas hidupnya sendiri. Hanya mempengaruhi yang demikian sajalah yang dapat disebut mendidik (Sutari Imam Barnadib, 1989:25).

Selanjutnya Lengeveld juga menyatakan bahwa pendidikan itu merupakan suatu gejala yang terjadi di dalam pergaulan antara orang dewasa dengan orang yang belum dewasa. Dan pendidikan itu timbul dalam situasi pergaulan apabila ada kewibawaan, yaitu apabila anak didik menerima kewibawaan pendidiknya.

Di negara kita ini, hal terkait pendidikan dijelaskan di dalam GBHN (Ketetapan MPR RI No. IV/MPR/1973) yang menyatakan bahwa: "Pendidikan pada hakekatnya adalah usaha sadar untuk mengembangkan kepribadian dan kemampuan di dalam dan di luar sekolah dan berlangsung seumur hidup." Dan menurut Ketentuan Umum, Bab I Pasal 1 UU Sistem Pendidikan Nasional No. 2 Tahun 1989, menjelaskan bahwa: "Pendidikan adalah usaha sadar untuk menyiapkan peserta didik melalui kegiatan bimbingan, pengajaran dan/atau latihan 
bagi perananya di masa yang akan datang." Dan menurut UU Sisdiknas No. 2 Tahun 2003, pada Bab I, Pasal 1, Ayat 1, menjelaskan bahwa pendidikan adalah: "Usaha sadar dan terencana untuk mewujudkan suasana belajar dan proses pembelajaran agar peserta didik secara aktif mengembangkan potensi dirinya untuk memiliki kekuatan spiritual keagamaan, pengendalian diri, kepribadian, kecerdasan, akhlak mulia serta keterampilan yang diperlukan dirinya, masyarakat, bangsa, dan negara. Sedangkan Tujuan pendidikan tertulis dalam UU No. 2 Tahun 1989 tentang Sistem Pendidikan Nasional, BAB II, pasal 4 yang berbunyi sebagai berikut. "Pendidikan nasional bertujuan mencerdaskan kehidupan bangsa dan mengembangkan manusia Indonesia seutuhnya, yaitu manusia yang beriman dan bertakwa terhadap Tuhan Yang Maha Esa dan berbudi pekerti luhur, memiliki pengetahuan dan keterampilan, kesehatan jasmani dan rohani, kepribadian yang mantap dan mandiri serta rasa tanggung jawab kemasyarakatan dan kebangsaan (Menteri Pendidikan dan Kebudayaan, 1994).”

Kutipan tujuan pendidikan nasional tersebut menyatakan dengan tegas bahwa pendidikan merupakan "mesin proses" pembinaan anak bangsa yang paling strategis, pendidikan menjadi faktor utama dalam rangka menciptakan manusia Indonesia yang ideal.

Dari ulasan di atas jelas bahwa pendidikan menjadi sesuatu yang sangat penting untuk kelangsungan hidup seseorang, terhormat atau tidak, mandiri atau tidak, susila atau asusila, akan tampak dari pendidikan yang dilaluinya. Dengan demikian dapat kita katakan bahwa begitu pentingnya pendidikan di masa sekarang ini. Pendidikan haruslah diperuntukkan untuk semua manusia, tiada terkecuali, untuk menentukan nasibnya sendiri, sehingga akhirnya mereka dapat menyumbang untuk kemajuan masyarakat di mana mereka tinggal. Memperoleh pengetahuan adalah suatu proses yang tidak pernah berakhir dan dapat diperkaya oleh semua bentuk pengalaman.

Mungkin perlu dikemukakan disini kenyataan yang sudah diketahui oleh semua orang, yang mempunyai dampak pada pendidikan yang barangkali belum diberi makna yang memadai, bahwa perbedaan antara pendidikan untuk laki-laki dan perempuan sudah kurang batasannya sekarang ini daripada beberapa tahun yang lampau. Untuk jelasnya, ada kemajuan yang digapai beberapa tahun terakhir ini: statisyik UNESCO menunjukkan umpamanya, bahwa rasio keaksaraan wanita sudah meningkat di hampir di semua negara dan ini didukung oleh data yang ada. Namun disparitas masih nyata: dua per tiga orangorangdewasa yang buta huruf di dunia atau 565 juta orang adalah wanita dan hampir semua bermukin di kawasan-kawasan berkembang di Afrika, Asia, dan Amerika Latin. Di seluruh dunia, lebih sedikit perempuan yang bersekolah daripada laki-laki: seorang dari empat perempuan berusia sekolah dasar tidak bersekolah (24,5\% atau 85 juta), sedangkan itu berlaku bagi seorang dari enam anak lelaki (16,4\% atau 60 juta). Disparitas ini dapat diterangkan terutama oleh situasi di kawasankawasan yang kurang berkembang itu. Umpamanya, di sub-Sahara Afrika, kurang dari 50\% anak perempuan berusia 6-11 tahun yang bersekolah, dan angka ini turun drastis pada kelompok umur yang lebih tinggi (Menteri Pendidikan dan Kebudayaan, 1994).

Tugas pendidikan adalah mengajar, pada saat yang sama dan sekaligus, akan keanekaragaman ras manusia dan kesadaran atas persamaan-persamaan antarmanusia, dan kemandirian antara sesama manusia. Dengan demikan, sejak masa kanak-kanan, sekolahsekolah harus menggunakan setiap kesempatan untuk mengajarkan pengetahuan kepada mereka. Jika seseorang hendak memahami orang lain, maka orang tersebut pertama-tama harus 
mengenal dirinya sendiri. Untuk memberikan kepada naka-anak dan kaum muda, pandangan yang tepat tentang dunia, maka pendidikan, apakah di dalam keluarga, masyarakat, atau sekolah, pertama-tama haruslah membantu mereka menemukan siapa mereka. Hanya dengan jalan demikian, mereka akan benar-benar mampu menempatkan dirinya di tempat-tempat orang lain dan memahami reaksi-reaksi mereka.

Salah satu tujuan dari pendidikan ialah meningkatkan peluang untuk mendapatkan pekerjaan, menjaga keluarga dari ancaman kemiskinan dan membantu mengikis perbedaan gender (gender gaps). Bagi perempuan yang berpendidikan, memiliki status sudah bekerja bukanlah hal yang utama, namun mereka harus memiliki pekerjaan yang mampu menjamin dan menyediakan lingkungan yang baik dan pendapatan yang layak. Secara khusus bagi perempuan, pendidikan akan membantu menghilangkan adanya perbedaan gender dalam hal peluang untuk mendapatkan pekerjaan dan pembayaran (gaji) yang sama dengan laki-laki.

Dengan dirayakannya tanggal 8 Maret sebagai hari perempuan Internasional, semoga semakin meningkatkan rasa peduli terhadap pendidikan kaum perempuan, sehingga tercipta perempuan yang mandiri, memiliki pemahaman yang baik tentang bagaimana menjaga nutrisi anak, melahirkan generasi yang berkualitas, mencegah keguguran serta keseimbangan dalam kehidupan sosial. Jika boleh meminjam kalimat Ban Ki-Moon (UN, Secretary General) bahwa "Women's empowerment works for men, too. Where men and women equal rights and opportunities, societies, prosper”. Dengan semakin tingginya pendidikan kaum perempuan semoga menjadi solusi jitu atas permasalahan bangsa kita saat ini.

Tentunya penelitian tentang masyarakat Betawi dengan segala budayanya sudah banyak dilakukan. Menarik karena daerah Ciputat belum ada yang mengangkat mengenai penelitian ini. Beberapa penelitian sejenis yang mengupas masalah masyarakat Betawi telah ditulis, di antaranya: (1) Yudha Auria Triatmaja, Jurusan: Psikologi, Universitas Gunadarma, Jakarta. Judul penelitian: "Perbedaan tingkat etnosentrisme pada orang Betawi dewasa awal yang memiliki pendidikan tinggi dengan yang memiliki pendidikan rendah.”

Menurut Yudha, Etnosentrisme adalah pandangan yang menganggap bahwa kelompok atau kebudayaan sendiri lebih baik daripada kelompok atau kebudayaan lainnya. Hal ini sering terlihat pada masyarakat Betawi yang berpendidikan rendah karena banyak dari mereka yang masih sangat bergantung kepada kelompoknya. Berbeda dengan masyarakat Betawi yang berpendidikan tinggi, dimana mereka memiliki sifat toleransi yang lebih baik. Karena dengan lebih berpendidikan dapat membuat seseorang lebih toleran dan tidak mudah terprovokasi sehingga tercapai kehidupan yang harmonis.

Penelitian ini bertujuan untuk mengetahui adanya perbedaan tingkat etnosentrisme antara orang Betawi dewasa awal yang berpendidikan tinggi dengan yang berpendidikan rendah. Metode yang digunakan dalam penelitian adalah metode kuantitatif dengan kuesioner sebagai instrumen pengumpul data. Hasil penelitian menunjukkan orang Betawi yang berpendidikan rendah mempunyai tingkat etnosentrisme yang lebih tinggi daripada yang berpendidikan tinggi.

Penelitian lainnya adalah (2) Ariesta Eka Susanti dkk, Universitas Gunadarma, 2009. Mereka meneliti tentang "Roti Buaya; Lambang Kesetiaan Masyarakat Betawi”. Unik sekaligus menarik, karena buaya dijadikan lambang kesetiaan oleh masyarakat Betawi. Hal ini diwujudkan dalam adat istiadat perkawinan. Hampir sebagian besar masyarakat Betawi jika melangsungkan perkawinan membawa seserahan berupa "Roti Buaya". Roti buaya yang digunakan sebagai salah satu seserahan ini, 
bermakna "kesetiaan", karena buaya merupakan hewan yang kawin satu kali seumur hidupnya. Oleh karena itu, bentuk roti ini tidak dapat digantikan dengan hewan lain seperti, kucing, ayam, kelinci dll, yang tidak memiliki kesetiaan seperti buaya. Masyarakat betawi berharap dengan membawa roti ini sebagai seserahan, kelangsungan hidup rumah tangga yang akan dijalani oleh pengantin akan langgeng hingga maut yang memisahkan. Roti ini juga menjadi doa bagi pasangan pengantin agar selalu setia terhadap pasanganya.

Penelitian selanjutnya, (3) Lance Castles yang pernah meneliti tentang Penduduk Jakarta di mana Jurnal Penelitiannya diterbitkan tahun 1967 oleh Cornell University mengatakan bahwa secara biologis, mereka yang mengaku sebagai orang Betawi adalah keturunan kaum berdarah campuran aneka suku dan bangsa yang didatangkan oleh Belanda ke Batavia. Kelompok etnis ini lahir dari perpaduan berbagai kelompok etnis lain yang sudah lebih dulu hidup di Jakarta, seperti orang Sunda, Melayu, Jawa, Bali, Bugis, Makassar,dan Ambon, serta suku-suku pendatang, seperti Arab, India, Tionghoa, dan Eropa.

Tulisan yang cukup menarik dari Budy Sugandy (Mahasiswa Master Program Technische Universitat Baraunschweig, Germany), dia menulis tentang "Urgensi Pendidikan bagi Perempuan”, 12 Maret 2014. Menurutnya, "Tingkat pendidikan yang berkualitas akan mampu menjadikan hidup lebih baik, khususnya bagi kaum perempuan. Pendidikan merupakan senjata penting untuk mengembangkan diri dan menggapai tujuan dari sebuah harapan. Ini merupakan tantangan bagi seluruh masyarakat Indonesia selaku objek dan pihak penanggung jawab dalam hal ini Pemerintah selaku penyelenggara untuk berusaha menjamin kualitas pendidikan bagi anak-anak dan pemuda Republik Indonesia, tanpa melihat dari latar belakang asal keluarga, dari mana mereka berasal, gender, suku, ras dan kecacatan (disapled), mereka semua harus memiliki kesamaan dalam penyelenggaraan penididikan. Pendidikan harus mampu memberikan ruang bagi perempuan untuk untuk meraih pendidikan tingkat tinggi, mendapatkan pekerjaan yang layak, jaminan kesehatan dan berpartisipasi aktif di masyarakat dan ini akan mendorong seluruh putra-putri Indonesia memiliki kesempatan untuk hidup sejahtera. Fenomena bahwa perempuan Indonesia masih banyak yang berpendidikan rendah menjadi angin yang tidak segar diera globalisasi saat ini. Untuk mewujudkan pendidikan berkualitas bagi kaum perempuan ini maka harus ada jaminan pendidikan bagi seluruh perempuan untuk tidak menamatkan pendidikan hanya sampai pada jenjang pendidikan dasar namun pada jenjang atas."

Dari ulasan di atas tampak bahwa pendididkan untuk perempuan tidak dapat dinomorduakan. Perempuan menjadi ujung tombak kelangsungan generasi bangsa ini. Mengapa sebagian orang masih menganggap tidak terlalu penting pendidikan untuk perempuan? Pada hal beberapa penelitian yang dilakukan oleh World Bank tahun 2007 (Policy Research Working Paper), menyebutkan bahwa:

a) Di El Salvador, hanya 5\% dari para pekerja dewasa dengan tingkat pendidikan maksimal sekolah dasar (primary education) yang mampu bekerja, berbanding dengan $47 \%$ dari para pekerja dewasa lulusan sekolah tingkat atas (secondary education) yang mampu bekerja.

b) Di United Republic of Tanzania, 82\% dari para pekerja dengan tingkat pendidikan maksimal sekolah dasar (primary education) hidup dibawah garis kemiskinan. Melalui usaha peningkatan pendidikan hingga tingkat atas (secondary school) mampu mengurangi peluang kemiskinan hingga $60 \%$. 
c) Di Pakistan, para pekerja perempuan dengan kecakapan dalam skill baca tulis (literacy) yang baik memiliki gaji 95\% lebih tinggi daripada perempuan yang lemah dalam skill membaca dan menulis.

d) Di daerah pedesaan di Indonesia, dengan adanya penambahan program wajib belajar mampu mengurangi peluang jatuh kembali ke dalam kemiskinan hingga 25\%.

Kita tidak dapat pungkiri bahwa masih banyak penduduk Indonesia yang memiliki pola pikir yang sama dengan hasil penelitian di atas, maksudnya pola pikir masyarakat kita masih ada yang menganggap bahwa pendidikan untuk perempuan tidak terlalu penting, artinya masih menomorsatukan pendidikan untuk laki-laki.

Hal ini mengusik pikiran saya untuk meneliti, apa sebenarnya yang terjadi di sekitar kita? Lingkungan yang berpendidikan apakah akan berdampak langsung pada pola pikir mereka yang memang susah hidup secara turun temurun dengan pola pikir yang tak mau diubah. Pendidikan menjadi sesuatu menakutkan atau sesuatu yang memberatkan? Banyak penelitian tentang masyarakat Betawi, khususnya mengenai kesenian, adat istiadat, makanan, acara pernikahan, dan sebagainya, akan tetapi sejauh ini saya belum menemukan penelitian yang terkait dengan pola pikir (konsep) tentang pendidikan bagi anak perempuan dalam masyarakat Betawi

Suku Betawi adalah salah satu suku di Indonesia yang penduduknya bertempat tinggal di wilayah Jakarta. Jakarta ibu kota negara menjadi tumpuan pendatang dari berbagai penjuru daerah di Indonesia. Pertambahan penduduk/pendatang menyebabkan penduduk asli/pribumi tersingkir ke pinggiran-pinggiran ibu kota, atau tepatnya ke daerah-daerah yang berbatasan dengan ibu kota. Pendatang tidak saja mempengaruhi pertumbuhan penduduk, akan tetapi mempengaruhi juga pola pikir pribumi setempat, yakni penduduk asli Jakarta yaitu masyarakat Betawi.

Masyarakat Betawi yang berdomisili di wiayah Ciputat sebagian besar adalah penduduk asli. Artinya mereka sudah tinggal di Ciputat secara turun-temurun. Mereka mewariskan tanah dari leluhur mereka. Walaupun, mungkin, tanah mereka sedikit demi sedikit mulai berkurang dikarenakan untuk menutupi kebutuhan hidup, mereka menjual tanah-tanah mereka.

Ciputat sekarang tentunya sangat berbeda dengan Ciputat awal tahun 70-an, Ciputat dahulu penuh dengan perkebunan dan persawahan. Udaranya pun masih sejuk, belum banyak penghuninya. Daerah Ciputat tidak terlalu luas, artinya keramaian hanya terpusat di Masjid Agung, Pasar, dan terminal, Koramil, Puskesmas, SD Ciputat, yang kesemuanya itu menyatu di satu tempat. Kendaraan angkutan yang hilir mudik pun hanya opelet, mobil kayu yang setiap pagi dan petang berisi tukang buah yang mengantar dagangannya dari Parung ke Ciputat, lalu Ciputat ke Kebayoran Lama. Lalulalang opelet pun cukup berjarak waktu lama, karena memang mobil itu tidak banyak. Rutinitas pagi anak-anak sekolah cenderung berjalan kaki, walaupun sampai Pondok Pinang, berjalan kaki adalah alternatif efektif karena lamanya menunggu opelet yang lewat.

Sekitar tahun 70-an penduduk laki-laki masyarakat Betawi cenderung bekerja sebagai pekerja kasar, seperti buruh bangunan, tukang sampah, atau tukang ojek, sering juga yang menjual jasa dalam jual beli tanah atau kendaraan, istilah lainnya menjadi calo. Pekerjaan mereka serabutan, artinya jarang sekali kita temui mereka bekerja di kantor atau di bidang pendidikan seperti guru. "Dulu mah, kita gak kepikiran kerja kantor, orang kebon kita luas, ayam ada, kambing, kebo juga banyak (Wawancara Pribadi).” Ujar Pak Agus yang di wawancarai di daerah Pamulang. 
Masyarakat Betawi seperti bapak Agus banyak kita temui di daerah sekitar Ciputat, di awal tahun 70 -an. Penduduk Ciputat pada saat itu pun masih terbilang sedikit, dan lahan masih banyak yang kosong, sepenjang jalan Ciputat Raya menuju Parung, terhampar kebun dan sawah yang luas. Gedung-gedung bertingkat pun belum ada. Gedung tertinggi yang dijumpai hanya ada gedung IAIN (Institut Agama Islam Negeri) Syarif Hidayatullah Jakarta, itu pun hanya dua lantai. Masyarakat pada waktu itu menyebutnya "Gedong Tinggi"

Perempuan-perempuan Betawi yang tidak memiliki lahan perkebunan atau pertanian, mereka mencari kesibukan dengan bekerja sebagai buruh paruh waktu di rumah-rumah pendatang yang ada di sekitar tempat tinggal mereka. Sebagai buruh atau pekerja di rumah tangga maka pekerjaan mereka sekitar, mencuci pakaian, menyeterika, dan tentunya bersihbersih rumah. Ada juga yang menjadi pengasuh bayi atau balita. Pendidikan mereka rata-rata adalah tamat sekolah dasar. Dari hasil wawancara dengan beberapa responden terlihat bahwa pemikiran mereka tentang pendidikan sudah mulai bergeser.

Seiring jalannya waktu dan perkembangan teknologi dan pendidikan, maka Ciputat padatahun 80-an menjadi Pusat Pengembangan Islam. IAIN yang waktu itu merupakan perguruan tinggi Islam terbesar di wilayah Jakarta, menjadi tempat tujuan para pencari ilmu dalam bidang agama. Para pemuda dari berbagai daerah., bahkan dari mancanegara datang untuk menuntut ilmu di IAIN. Beberapa negara yang banyak mengirimkan mahasiswanya adalah: Malaysia, Singapura, Thailand, Tanzania, dan Korea.

Perkembangan IAIN yang begitu mendunia ternyata tidak terlalu berefek positif terhadap masyarakat sekitar, artinya tidak banyak masyarakat sekitar yang mau kuliah ke IAIN, hususnya masyarakat Betawi Ciputat.
Hiruk-pikuk kampus tidak berpengaruh tehadap pendidikan masyarakat Betawi. Masyarakat Betawi justru menjual tanah-tanah mereka kepada pendatang. Dengan demikian, tanahtanah mereka lambat laun habis, dan tersisa sedikit lahan hanya untuk tempat tinggal.

Di awal tahun 70-an, di daerah Ciputat terdapat Sekolah Dasar Negeri (SDN) hanya ada 3 yaitu, SDN Legoso, SDN Gintung, dan SDN Ciputat. Bagaimana dengan SMP dan SMA? Pastinya belum ada. SMPN terdekat adalah di Pondok Pinang SMPN 87, dan PGAN 6 tahun juga di Pondok Pinang, Jakarta Selatan. Untuk daerah Ciputat sendiri tidak ada, jadi, anak-anak yang ingin melanjutkan sekolah harus pergi ke daerah Jakarta. Pada waktu itu yang melanjutkan sekolah kebanyakan anak-anak dari pendatang, untuk penduduk asli Betawi sendiri memilih berehenti hanya sampai di SD saja. Beberapa dari mereka selepas SD menikah. Ada juga yang membantu orang tua mereka berdagang atau berkebun.

Tingkat pendidikan yang berkualitas akan mampu menjadikan hidup lebih baik, khususnya bagi kaum perempuan. Pendidikan merupakan senjata penting untuk mengembangkan diri dan menggapai tujuan dari sebuah harapan. Ini merupakan tantangan bagi seluruh masyarakat Indonesia selaku objek dan pihak penanggung jawab dalam hal ini Pemerintah selaku penyelenggara untuk berusaha menjamin kualitas pendidikan bagi anak-anak dan pemuda Republik Indonesia, tanpa melihat dari latar belakang asal keluarga, dari mana mereka berasal, gender, suku, ras dan kecacatan (disabled), mereka semua harus memiliki kesamaan dalam penyelenggaraan penididikan. Pendidikan harus mampu memberikan ruang bagi perempuan untuk untuk meraih pendidikan tingkat tinggi, mendapatkan pekerjaan yang layak, jaminan kesehatan dan berpartisipasi aktif di masyarakat dan ini akan mendorong seluruh 
putra-putri Indonesia memiliki kesempatan untuk hidup sejahtera.

Fenomena bahwa perempuan Indonesia masih banyak yang berpendidikan rendah menjadi angin yang tidak segar diera globalisasi saat ini. Anggapan bahwa perempuan hanya berfungsi sebagai $3 \mathrm{R}$ yaitu dapur, sumur, dan kasur harus segera di-replace sehingga tidak ada lagi ketimpangan sosial. Untuk mewujudkan pendidikan berkualitas bagi kaum perempuan ini maka harus ada jaminan pendidikan bagi seluruh perempuan untuk tidak menamatkan pendidikan hanya sampai pada jenjang pendidikan dasar namun pada jenjang atas. Dan peningkatan jenjang pendidikan harus ditunjang dengan fasilitas yang mendukung serta kualitas yang baik.

Berdasarkan hasil wawancara peneliti didapatkan data bahwasanya masyarakat Betawi di daerah Ciputat sudah memiliki pandangan yang positif terhadap pendidikan, seperti data tabel tentang pendidikan anak-anak responden di bawah ini.

\section{Tabel 1}

Data Pendidikan Anak-Anak Responden

\begin{tabular}{lllllll}
\hline No. & Reponden & SD & SMP & SMA & S1 & Jumlah \\
\hline $\mathbf{1}$ & Ibu Susi & 0 & 0 & 0 & 4 & 4 \\
$\mathbf{2}$ & Ibu Rina & 0 & 1 & 1 & 1 & 3 \\
$\mathbf{3}$ & Ibu Yanti & 1 & 1 & 0 & 1 & 3 \\
$\mathbf{4}$ & Bapak & 1 & 1 & 1 & 1 & 4 \\
& Agus & & & & & \\
$\mathbf{5}$ & Ibu Wati & 0 & 0 & 1 & 2 & 3 \\
$\mathbf{6}$ & Bapak & 0 & 1 & 1 & 2 & 4 \\
& Nurul & & & & & \\
$\mathbf{7}$ & Ibu Neni & 0 & 0 & 2 & 0 & 2 \\
$\mathbf{8}$ & Ibu Ijah & 0 & 0 & 6 & 0 & 6 \\
$\mathbf{9}$ & Ibu Ana & 0 & 0 & 3 & 0 & 3 \\
$\mathbf{1 0}$ & Ibu Lili & 0 & 0 & 4 & 0 & 4 \\
& Jumlah & 2 & 4 & 19 & 11 & 36 \\
\hline
\end{tabular}

Tabel di atas menunjukkan bahwa tingkat pendidikan untuk Strata 1 ternyata paling tinggi 11 orang, ini berarti kesadaran akan pendidikan masyarakat Ciputat bagus. Pada ibu Susi sebagai orang Betawi asli merasa pentingnya pendidikan karena tempat tinggal atau rumah kediamannya berdekatan dengan kampus. Menurut ibu Susi, "Kehadiran IAIN, salah satu penyebab berubahnya pola pikir mengenai pendidikan masyarakat Betawi di Ciputat (Wawancara Pribadi)" Hal ini tentunya didukung juga dengan faktor ekonomi keluarga. Karena secara finansial keluarga Ibu Susi cukup mampu, memiliki banyak tanah dan membuka beberapa usaha sarana olah raga dan toko kelontong yang disewakan. Wajar saja jika anak-anak ibu Susi semua kuliah, malah dua anaknya sudah lulus dari kuliahnya dan sudah bekerja.

Berbeda dengan ibu Nani, karena ekonomi yang pas-pasan, bekerja hanya sebagai pedagang nasi uduk, merasa anaknya tamat SMA saja sudah cukup bagus. Jadi, faktor keuangan menjadi sangat penting dalam pendidikan bagi mereka. Ibu Nani menyatakan bahwa, "Udah tamat SMA saja itu sudah bagus, asal jangan SD, nanti bisa dibodohi orang (Wawancara Pribadi).

Keluarga ibu Nani tinggal tak berjauhan dengan kampus UIN, tapi karena faktor ekonomi tidak member kesempatan pada keluarga atau anak-anak mereka untuk kuliah, bekerja adalah alternative yang utama, untuk menopang ekonomi keluarga. Anak perempuan bu Nani hanya tamat SMA, dan bekerja sebagai penjaga toko. Itupun sudah cukup menyenangkan hati ibu Nani, seperti komentarnya kepada peneliti di observasi awal. "Anak gua sih, Cuma tamat SMA, tapi dia udah kerja itu aja udah nyenengi banget hati gua, itung-itung ngebantu ngeringanin belanja dah (Wawancara Pribadi).”

Pola pikir mereka tentang pendidikan mulai berubah khususnya pada pendidikan anak perempuan, seperti komentar ibu Susi ketika diwawancarai oleh peneliti, "Kondisi perempuan Betawi sekarang berbeda, saya sendiri memberi kebebasan sekolah setinggi-tingginya untuk anak-anak, baik yang laki maupun yang 
perempuan, kita cuma menyiapkan biayanya saja (Wawancara Pribadi).”

Begitu juga pendapat ibu Rina yang tinggal di Kelurahan Cempaka Putih menyatakan, "Pendidikan itu penting untuk semuanya, baik anak laki-laki maupun anak perempuan (Wawancara Pribadi).”

Dengan memperolehnya pendidikan yang tinggi tentunya akan mengubah pola pikir dan bertambahnya wawasan seseorang. Ternyata faktor lain yang membuat mereka merasa penting memberikan pendidikan tinggi adalah agar anak-anak mereka kelak mendapatkan kesempatan kerja yang lebih baik. Seperti yang dituturkan ibu Wati dalam wawancaranya, "Status kependidikan juga diperlukan untuk kepentingan memperoleh pekerjaan yang layak dan perbaikan hidup secara ekonomi maupun mental (Wawancara Pribadi).”

Menurut ibu Wati, status di masyarakat sangatlah penting. Status itu akan terangkat salah satunya dengan pendidikan yang tinggi, yaitu kuliah. Di samping akan menunjukkan status yang lebih baik, pastinya juga akan membuka peluang kerja yang lebih banyak. Maka kesempatan untuk memperbaiki ekonomi keluarga akan mudah. Di samping itu juga mental anak-anak yang sudah menjalani pendidikan di perguruan tinggi akan berbeda dengan mental anak yang hanya tamat SMA. Pendidikan di perguruan tinggi akan membuat seorang anak lebih dewasa dan banyak pengalaman. Di antaranya pengalaman berorganisasi dan berkomunikasi dengan pihakpihak pemerintahan atau birokrasi negara.

Tabel 2. Data Latar Belakang Pendidikan Responden

\begin{tabular}{lllllll}
\hline No. & Reponden & SD & SMP & SMA & S1 & S2 \\
\hline 1 & Ibu Susi & & & & & $\sqrt{ }$ \\
2 & Ibu Rina & & & $\sqrt{ }$ & & \\
3 & Ibu Yanti & & & $\sqrt{ }$ & & \\
$\mathbf{4}$ & Bapak & & & & $\sqrt{ }$ & \\
\hline
\end{tabular}

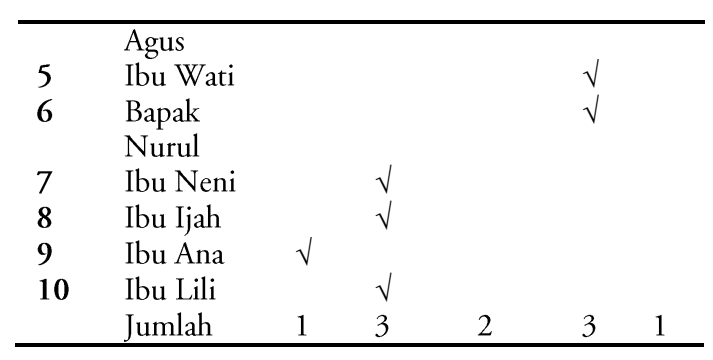

Dari tabel di atas Nampak bahwa ternayata ditemukan responden yang telah menyelesaikan S2 sebanyak satu orang yaitu, ibu Susi. Dari dara observasi dan wawancara awal, mengapa ibu Susi bersekolah sampai S2 ternyata karena tuntutan pekerjaan. "Saya kuliah lagi, sebenarnya karena tuntutan pekerjaan artinya, jika kita ingin meningkatkan kualitas kerja ya, sebaiknya kita kuliah lagi (Wawancara Pribadi)". Tidak banyak masyarakat Betawi, khususnya yang perempuan yang punya keinginan atau kesempatan untuk melanjutkan pendidikan. karena walau bagaimanapun biaya pendidikan sekarang ini, untuk $S 1$ atau pun S2, cukup tinggi. Ibu Susi melanjutkan kuliah dikarenakan tuntutan pekerjaan dan juga memiliki kemampuan finasial, karena didukung oleh perekonomian keluarga besarnya yang cukup kaya.

Sedangkan untuk ibu Wati, Bapak Agus, dan Bapak Nurul, mereka menamatkan S1, menurut mereka itu sudah cukup mumpuni untuk mencari pekerjaan dalam menghidupkan keluarga. Ibu wati yang juga sebagai PNS, seorang guru $\mathrm{SD}$, merasa sangat beruntung dengan kondisi pendidikannya sebagai S1. "Saya sangat berterima kasih kepada orang tua saya yang telah menyekolahkan saya sampai sarjana, jadi saya dapat menikmati hidup yang lebih baik dari temen-temen yang tidak kuliah, minimal status sosial keluarga saya terangkat, karena saya sarjana (Wawancara Pribadi).” Karena hal ini pula akhirnya Ibu Wati, menyekolahkan anakanaknya sampai ke perguruan tinggi.

Ibu Nani yang pedagang nasi uduk karena hanya tamat SMP lalu dinikahkan, maka dia 
merasa bahwa pendidikan tinggi tidak terlalu penting, responden mengatakan tamat SMA saja sudah cukup bagus. Hal ini disebabkan oleh pengalaman pendidikan responden sendiri.

Faktor pendidikan orang tua secara langsung sangat berpengaruh terhadap pola pikir pendidikan anggota keluarga, apalagi jika dia seorang ibu. Seorang ibu yang setiap hari berhubungan langsung dengan anak-anak mereka. Sama halnya dengan ibu Ijah yang memiliki putra 6 orang, mereka hanya tamat SMP dan tamatan SMA dan langsung bekerja, tidak berniat melanjutkan kuliah karena bu Ijah sendiri tidak punya pengalaman sekolah tinggi.

Dari hasil tabel tampak bahwa semakin tinggi pendidikan responden maka dia akan memberikan kesempatan pendidikan pada anakanaknya untuk bersekolah tinggi. Pola pikir ini akan terus berlanjut jika mereka tidak tersentuh dengan dunia teknologi yang semakin canggih.

Dari tabel di atas tampak ada seorang responden yang tamat $\mathrm{SD}$, tiga tamat $\mathrm{SMP}$, dan dua responden tama SMA, ada juga yang tamat S1 sebanyak 3 orang, dan Magister 1 orang. Hal ini menunjukkan gugurnya pernyataan "Betawi malas sekolah" karena ternyata ditemukan responden yang telah sarjana dan ada yang magister satu orang yaitu ibu Susi.

Tabel 3. Data Latar Belakang Pekerjaan Responden

\begin{tabular}{llllll}
\hline No. & Reponden & PNS & Swasta & Dagang & $\begin{array}{c}\text { Rumah } \\
\text { Tangga }\end{array}$ \\
\hline $\mathbf{1}$ & Ibu Susi & $\sqrt{ }$ & & & \\
$\mathbf{2}$ & Ibu Rina & $\sqrt{ }$ & & & $\sqrt{ }$ \\
$\mathbf{3}$ & Ibu Yanti & & $\sqrt{ }$ & & \\
$\mathbf{4}$ & Bapak & & $\sqrt{ }$ & & \\
& Agus & & & & \\
$\mathbf{5}$ & Ibu Wati & $\sqrt{ }$ & & & \\
$\mathbf{6}$ & Bapak & & $\sqrt{ }$ & & \\
& Nurul & & & $\sqrt{ }$ & \\
$\mathbf{7}$ & Ibu Neni & & & $\sqrt{ }$ & \\
$\mathbf{8}$ & Ibu Ijah & & & & $\sqrt{ }$ \\
$\mathbf{9}$ & Ibu Ana & & & & $\sqrt{ }$ \\
$\mathbf{1 0}$ & Ibu Lili & & & 2 & 3 \\
\hline & Jumlah & 3 & 2 & 2 & \\
\hline
\end{tabular}

Latar pekerjaan responden pun beragam dari mulai ibu rumah tangga, dagang, pegawai swasta sampai pegawai negeri. Terdapat 3 orang PNS, hal ini menunjukkan bahwa orang Betawi sudah terbuka pola pikirnya mengenai pendidikan. mengapa saya katakana demikian? Karena latar belakang keluarga responden bukanlah dari keluarga yang berpendidikan tinggi, artinya kesadaran sekolah orang tua mereka sudah cukup baik. Hal ini berimbas pada pola mereka mengasuh anak-anak mereka, ternyata anak-anak mereka melanjutkan pendidikan ke perguruan tinggi. Karena menurut mereka ketika mereka mendapat gelar S1, maka status sosial mereka di masyarakat akan terangkat. Seperti tuturan ibu Wati, "Status pendidikan yang diperlukan untuk kepentingan memperoleh pekerjaan yang diinginkan baik untuk memperoleh atau mengubah status atau pernaikan hidup secara ekonomi maupun mental (Wawancara Pribadi)."

Jelaslah, bahwa keterkaitan pengalaman ibu Wati bersekolah menjadi pembelajarn untuk anak-anaknya. Akan tetapi tidak kalah menariknya adalah dengan ibu Rina dan ibu Yanti, walaupun responden hanya taman SMA, tetapi mereka menyekolahkan anak-anak mereka ke perguruan tinggi, alasan responden antara lain adalah, "Zaman semakin canggih, maka tuntutan semakin tinggi (Wawancara Pribadi).” Ibu Yanti yang kebetulan anaknya kuliah di UIN Jakarta di Fakultas Ekonomi dan Bisnis ini merasa bahwa kehadiran UIN mengubah pola pikir keluarganya. Memang keluarga responden tidak ada yang sekolah ke perguruan tinggi, karena ibunya hanya tamat SD, tetapi berangkat dari pengalaman itulah akhirnya ibu Yanti menyekolahkan anaknya ke prguruan tinggi. Sama halnya sengan ibu Rina, keluarga besarnya tidak ada yang sekolah ke perguruan tinggi, ibu yang sudah ditinggal mati suaminya ini bertekad menyekolahkan ketiga putrinya sampai ke perguruan tinggi. "Sekarang pendidikan itu harus sama laki-laki dan perempuan, apalagi 
perempuan harus tinggi karena nanti biar gak tergantung sama suami (Wawancara Pribadi).” Komentar ibu Rina pula.

Jadi, ternyata konsep pendidikan untuk anak perempuan masyarakatBetawi di daerah Ciputat, cukup baik, artinya para orang tua belajar dari pengalaman mereka masing-masing. Responden tidak ingn anak-anak perempuan mereka sepreti mereka yang berpendidikan rendah, mereka ingin kehidupan anak-anak perempuan mereka di masa depan lebih baik dari mereka.

\section{Simpulan}

Hasil penelitian ini menunjukkan bahwa pola pikir masyarakat Betawi Ciputat sudah cukup tinggi terhadap pendidikan. Hal ini ditunjukkan dengan data sebanyak 11 orang dari 23 anak, yang telah melanjutkan kuliah. Dan 8 orang dari 11 itu adalah anak perempuan. Ini berarti pola asuh keluarga dalam pendidikan sudah cukup baik. Tidak tampak lagi perbedaan kesempatan untuk melanjutkan pendidikan. Semua responden memberikan pendapat yang sama dalam hal keahlian yang harus dimiliki oleh anak perempuan, yaitu harus pandai dalam hal mengurus urusan rumah tangga, walaupun pendidikan tinggi tapi tidak boleh meninggalkan keahlian dalam memasak, mengurus rumah, menjahit, dan semua hal yang terkait dengan kewanitaan.

\section{Daftar Pustaka}

Ary, Donald, dkk., 2010, Introduction to Research in Education $8^{\text {th }}$ edition. Wardswoth Cengage Learning, Canada: Nelson Education ltd., 2010

Barnadib, Sutari Imam, 1989, Pengantar Ilmu Mendidik Sistematis, Yogyakarta: Andi Offset.

Cresswell, Jhon W., 2012, Eduactional Research: Planning, Conducting, and Evaluating
Quantitative and Qualitative Research, Ney Jersey: Person Education, Inc.

Emzir. Metodologi Penelitian Pendidikan Kuantitatif \& Kualitatif. Jakarta: RajaGrafindo, 2011.

Menteri Negara Pemberdayaan Perempuan dan Perlindungan Anak dalam seminar teleconference Koalisi Kependudukan bertema: 'Perempuan dan Keluarga Indonesia di antara 7 Miliar Penduduk Dunia' di BKKBN Pusat Jakarta, Selasa (24/4/2012).

Menteri Pendidikan dan Kebudayaan, 1994, Undang-Undang Sistem Pendidikan Nasional, Jakarta: Sinar Grafika.

Napitupulu, W.P., 1999, Komisi Internasional Pendidikan Abad XXI, Belajar Harta Karun di Dalamnya, Paris: Penerbitan UNESCO.

Nazir, Moh., 2011, Metode Penelitian, Bogor: Ghalia Indonesia.

Purwanto, Ngalim. Psikologi Pendidilan. Bandung: Remaja Rosdakarya, 1987.

Sugiyono, 2012, Metode Penelitian Pendidikan Pendekatan Kuantitatif, Kualitatif, dan R\&D, Bandung: Alfabeta.

Suparlan, Parsudi, 1996, Pengantar Metode Penulisan: Pendekatan Kualitatif, Jakarta: Rajawali Press.

Wawancara Pribadi dengan bapak Agus, Pamulang, Sabtu, 13 Agustus 2016, pukul 10.00 .

Wawancara Pribadi dengan Ibu Susi, Ciputat, Selasa, 9 Agustus 2016, pukul 15.00.

Wawancara Pribadi dengan Ibu Nani, Pisangan, Minggu, 21 Agustus 2016, pukul 07.30.

Wawancara Pribadi dengan Ibu Rina, Cempaka Putih, Sabtu, 13 Agustus 2016, pukul 19.30 .

Wawancara Pribadi dengan Ibu Wati, Serua, Minggu, 14 Agustus 2016, pukul 10.00.

Wawancara pribadi dengan Ibu Yanti, Sabtu, 15 Agustus 2016, pukul 20.30. 